\section{Intrusion pathway of invasive Asian subterranean termite, Coptotermes gestroi (Wasmann) from the Neotropics into the Indian mainland}

\author{
T. Venkatesan ${ }^{1, *}$, C. M. Kalleshwaraswamy ${ }^{2}$, \\ Ankita Gupta ${ }^{1}$ and T. R. Ashika ${ }^{1}$
}

${ }^{1}$ ICAR-National Bureau of Agricultural Insect Resources, Post Box No. 2491, H.A. Farm Post, Hebbal, Bengaluru 560 024, India

${ }^{2}$ Department of Entomology, College of Agriculture, University of

Agricultural and Horticultural Sciences, Shivamogga 577 204, India

Coptotermes is one of the most widespread subterranean termite genus of economic significance with few species considered as truly invasive. Coptotermes gestroi (Wasmann) is also known to be invasive and has taxonomic confusion on its correct identity. Originally described from Myanmar, it is considered to occur in North East India and Thailand. However, it is found to cause serious economic losses in some Asian countries, Brazil, the Caribbean islands and peninsular Florida, USA. In the present study, the insect specimens which were recovered from imported wooden packaging material of a consignment at Goa, India, received from Harrisonburg, Virginia, USA have been reported. The termite species received was identified as $C$. gestroi through morphological characters and DNA barcoding. The possible infliction caused if invasive populations of $C$. gestroi enters India, in particular southern India, is discussed.

Keywords: Coptotermes gestroi, intrusion pathway, invasive species, morphological and molecular identification, subterranean termites.

Coptotermes Wasmann (Blattodea: Isoptera: Rhinotermitidae) is widespread and few species are among the world's highly threatening wood pests. The Asian subterranean termite, Coptotermes gestroi (Wasmann) and the Formosan subterranean termite, Coptotermes fomosanus Shiraki are the two most devastating termite species in the world which cause an annual loss of US \$40 billion ${ }^{1}$. Buczkowski and Bertelsmeier ${ }^{2}$ through predictive climate modelling provided risk assessment for 13 of the world's most invasive termites, which include $C$. gestroi at a global scale. Among several species of Coptotermes, $C$. gestroi is infamously known to be invasive and has taxonomic confusion on its correct identity. The species was first described from Myanmar (formerly Burma; Wasmann 1902) and was believed to occur only in this region, including Thailand and North East India ${ }^{3}$. Due to morphological variation in a few characters, new species names were given, but eventually synonyms were given and adopted in India, the Pacific Islands, Pakistan and

\footnotetext{
*For correspondence. (e-mail: Venkatesan.T@icar.gov.in)
}

Southeast Asia. In the Neotropical region, C. gestroi was first described as $C$. vastator and then under the name $C$. havilandi Holmgren it spread from Asia to Brazil in 1936, into the Caribbean ${ }^{4}$, and into peninsular Florida, USA $^{5}$.

Along with the junior synonyms for $C$. gestroi, such as the destructive $C$. heimi (Wasmann) ${ }^{6}$, confusion and misidentification with other valid species of the genus have also commonly occurred. In Southeast Asia, C. gestroi was sometimes wrongly identified as $C$. travians (Haviland), whereas the true $C$. travians was also misidentified as $C$. havilandi in peninsular Malaysia ${ }^{7}$. In the Pacific Islands, $C$. gestro $i$ was mistakenly identified as $C$. formosanus in Guam ${ }^{8,9}$. As described by Li et al. ${ }^{10}$, the following are all now considered as junior synonyms of C. gestroi: C. havilandi Holmgren, C. heimi (Wasmann), C. javanicus Kemner, C. obliqus Xia and He, C. pacificus Light, $C$. parvulus Holmgren, $C$. vastator Light, and $C$. yaxianensis $\mathrm{Li}$. In addition, although it is yet to be formally synonymized, the Sri Lankan species, C. ceylonicus Holmgren was also considered as a part of the $C$. gestroi complex ${ }^{11}$, and similar enough in morphology to C. gestroi to possibly be the same species. Due to such confusions, the actual occurrence of $C$. gestroi in India is in doubt, which needs thorough sampling and taxonomic studies. After a report by Roonwal and Chhotani ${ }^{3}$, there is no clear evidence of its presence in India. Maiti ${ }^{12}$ clearly mentions that the holotype was not designated by Wasmann and syntype was not traceable in Wassman's collections in the Natural History Museum, Maastricht, The Netherlands. In the fauna of Indian Isoptera (termites) and the adjacent countries ${ }^{3}$ and in the taxonomic monograph published by Maiti $^{12}$, there is no description of imago stages. Hence the report of swarming of $C$. gestroi in north-eastern Puducherry by Harit et al. ${ }^{13}$ is doubtful, wherein they have identified the species based on the imago caste which the previous taxonomists have not described from India so far. Harit et al. ${ }^{13}$ also cited the publication by Rathore and Bhattacharyya ${ }^{14}$ which documents the fauna of termites in Gujarat, where the species does not exist, nor does the publication contain the species description of $C$. gestroi. Our strong emphasis here is on the fact that if the species is present in India, it has not been collected and described after 1961. Krishna et al. ${ }^{15}$ considered only 21 Coptotermes species as valid among 69 species described worldwide. Out of the 69 valid species listed by them ${ }^{15}, 50 \%$ is described from limited material (e.g. one caste described, single colony of origin, or a single alate, etc. $)^{11}$. Another lacuna in these studies was that there was no comparison with previously described specimens. Hence thorough scrutiny of the validity of Indian Coptotermes is warranted. Further, there is a need of describing imago caste to avoid confusion.

Among 21 valid Coptotermes species, 16 are considered as largely invasive. In this study, the presence of C. gestroi collected from imported wooden packaging 


\section{RESEARCH COMMUNICATIONS}

Table 1. Measurements of Coptotermes gestroi imagoes received in comparison to previous studies ${ }^{7,24}$

\begin{tabular}{llcc}
\hline & \multicolumn{1}{c}{ Characters } & Present study material & ${\text { Kirton and Brown }{ }^{7} \text { Li et al. }^{24}}{ }^{24}$ \\
1 & Head length to tip of labrum & $1.45-1.52$ & $1.34-1.66$ \\
3 & Head length to lateral base of mandible & $1.08-1.12$ & $0.85-1.15$ \\
4 & Maximum head width & $1.38-1.50$ & $1.34-1.53$ \\
5 & Maximum diameter of eyes & $0.38-0.42$ & $0.39-0.46$ \\
6 & Minimum diameter of eyes & $0.35-0.40$ & $0.34-0.40$ \\
7 & Maximum diameter of ocellus & $0.15-0.17$ & $0.13-0.18$ \\
8 & Minimum diameter of ocellus & $0.10-0.12$ & $0.10-0.13$ \\
9 & Maximum width of pronotum & $1.25-1.30$ & $1.14-1.44$ \\
\hline$N=6$. & Minimum width of pronotum & $0.75-0.80$ & $0.76-0.94$
\end{tabular}
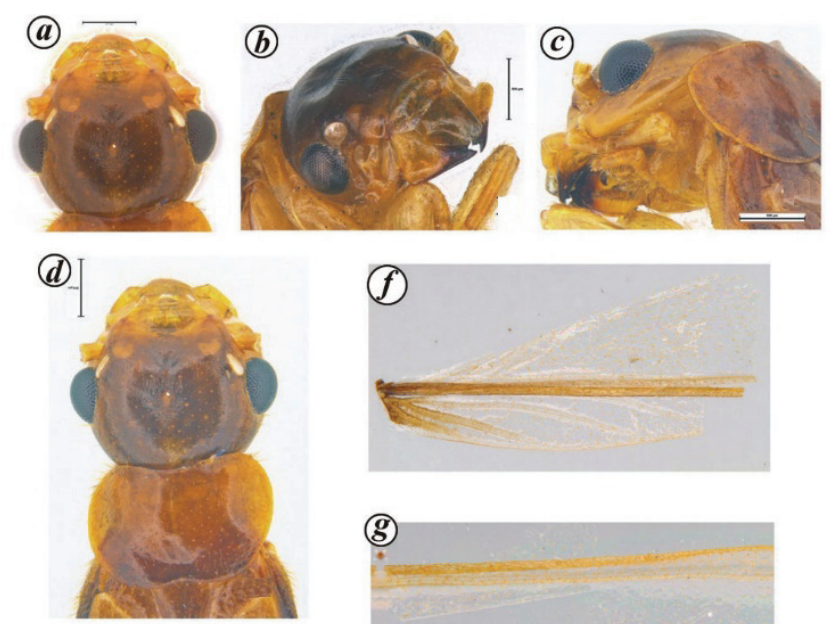

(e)
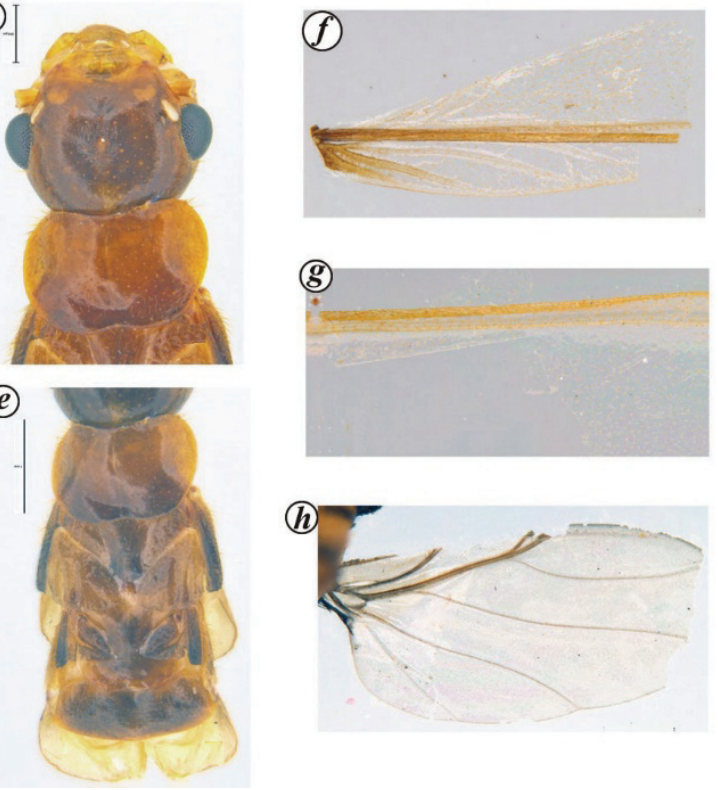

Figure 1. a, Head (dorsal view); b, head (mandibles in view); $\boldsymbol{c}$, head (lateral view); $\boldsymbol{d}$, head with pronotum; $\boldsymbol{e}$, thorax in part; $\boldsymbol{f}-\boldsymbol{h}$, wing remnants.

from Harrisonburg, Virginia, USA, has been reported. The possible infliction caused, if entered, is discussed.

Dead insect specimens (approximately 50 nos) were found in the packaging material. The imago specimens were used for morphological identification. The morphological characters examined were photographed using Leica M205C (Wetzlar and Mannheim, Germany) which has auto montage facility. The samples of $C$. gestroi received were imagoes and majority were damaged. Morphological comparison was made with previously published materials and measurements of $C$. gestroi imagoes were found to agree with those given by Kirton and Brown $^{7}$ (Table 1). Head capsule colour light to moderate dark brown. Head subcircular with length almost similar to width (head length $1.45 \mathrm{~mm}$; maximum head width $1.38 \mathrm{~mm}$ ) and covered with several setae. Antenna with 19-21 segments; first and second sparsely hairy, remaining hairy; first cylindrical, longest; second cylindrical, shorter and narrower than the first; third shortest; third to twentieth moniliform, last antennomere elongate elliptic. Labrum with anterior margin broadly rounded, broadest at middle, sides slightly converging posteriorly; central area convex; anterior border transparent; anterior with six long setae, central area with several long setae. Eyes subcircular (maximum diameter $0.38 \mathrm{~mm}$; minimum diameter $0.35 \mathrm{~mm}$ ). Ocellus elongated (maximum diameter $0.15 \mathrm{~mm}$; minimum diameter $0.10 \mathrm{~mm}$ ). Pronotum flat, brownish, narrower than the head, wider anteriorly, posterior margin with median notch and densely hairy. Abdomen oblong, densely hairy. Wings membrane hairy with brownish veins (Table 1 and Figure 1).

The specimens were further processed for molecular identification and voucher specimens were deposited in the National Insect Museum of National Bureau of Agricultural Insect Resources (NBAIR), Bengaluru, India. Further, the identity of the specimen was confirmed through DNA barcoding by amplifying the $\mathrm{CO} 1$ gene. A small tissue of the specimen was used for DNA extraction employing the Qiagen DNeasy ${ }^{\circledR}$ kit and the remaining parts of the specimen were stored as voucher at $70^{\circ} \mathrm{C}$ at NBAIR. DNA was used for PCR amplification of the $5^{\prime}$-terminus of $\mathrm{CO} 1$ gene $(658 \mathrm{bp})^{16}$. The following primers, viz. forward: LCO 1490 5'-GGTCAACAAATCATAAAGATATTGG-3' and reverse: HCO 2198 5'-TAAACTTCAGGGTGACCAAAAAATCA-3' were used for amplification of the CO1 gene. PCR reaction was carried out in $200 \mu \mathrm{l}$ volume, flat-capped tubes which had $50 \mu \mathrm{l}$ reaction volume containing: $5 \mu \mathrm{l} \mathrm{GeNeiTM} \mathrm{Taq} \mathrm{buffer,} 1 \mu \mathrm{l}$ GeNeiTM, $10 \mathrm{mM}$ dNTP mix, $1 \mu \mathrm{l}(20 \mathrm{pmol} / \mu \mathrm{l})$ forward primer $1 \mu \mathrm{l}(20 \mathrm{pmol} / \mu \mathrm{l})$ reverse primer $1 \mu \mathrm{l}$, GeNeiTM Taq DNA polymerase $(1 \mathrm{U} / \mu \mathrm{l}), 5 \mu \mathrm{l}$ DNA $(50 \mathrm{ng} / \mu \mathrm{l})$ and $36 \mu \mathrm{l}$ sterile water. Standard PCR conditions were followed using a BioRad C1000 ${ }^{\mathrm{TM}}$ Thermal Cycler. The amplified products were viewed on $1.5 \%$ agarose gel electrophoresis ${ }^{17}$ and sequenced using the ABI3130 (M/S Chromous, Bengaluru, India) platform. The samples were 


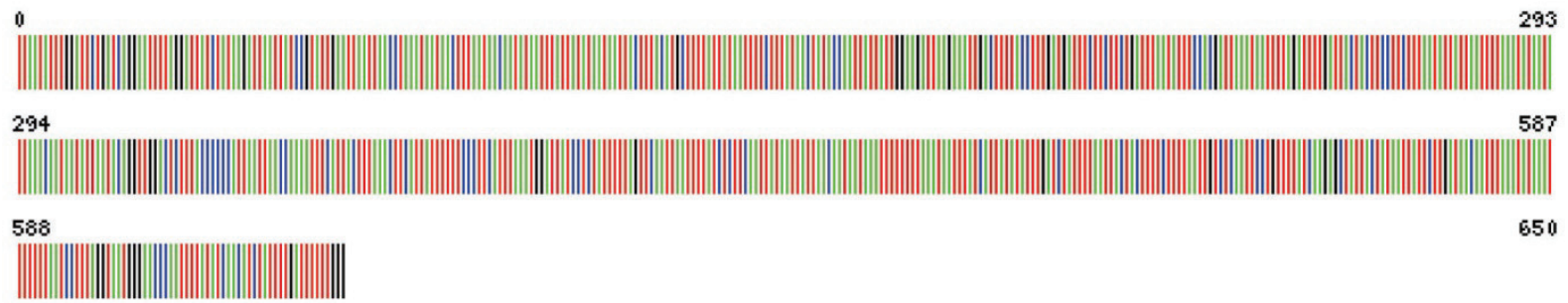

Figure 2. DNA barcode of Coptotermes gestroi with accession number MW575256.
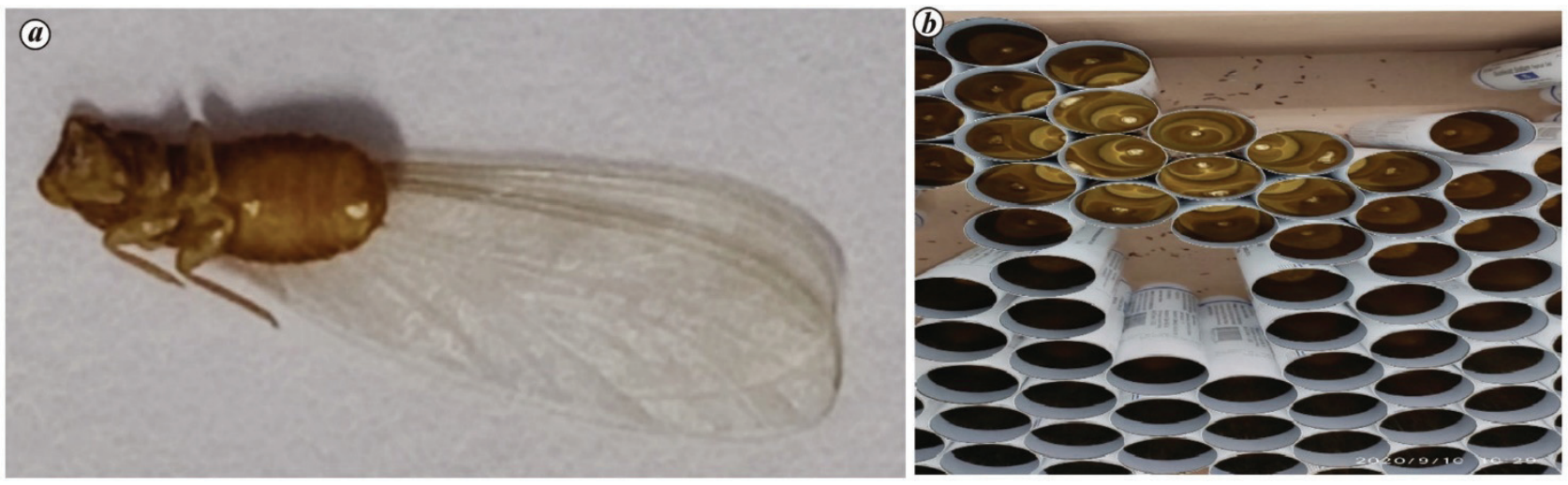

Figure 3. Dead insects and their parts observed in the packing material corrugated box after deboxing. $\boldsymbol{a}$, Collected termite species. $\boldsymbol{b}$, Photograph of the corrugated box in which termites were observed.

checked for homology, insertions and deletions, stop codons and frame shifts using NCBI-BLAST and ORF finder. Blast analysis revealed that the sequence obtained showed 99\% match to KC887198 (China), KC887197 (China) and KJ934505 (Malaysia). Further the specimen was confirmed as Coptotermes gestroi and GenBank accession number (MW575256) was received. DNA barcode was obtained from BOLD systems (Figure 2).

So far, around 28 termite species are considered as invasive and among them genus Coptotermes is known to cause significant economic loss around the world ${ }^{2,10,18}$. Recently, two species of Coptotermes, viz., C. testaceus and $C$. sjöstedti have been intercepted in India ${ }^{19}$ and thus it is important to have continuous monitoring of any invasive species entering the country. The negative impact of $C$. gestroi is huge involving environmental, economic ${ }^{7}$ and social (where historic structures are at risk) aspects $^{5,20}$. According to the global projection of termite invasion risks under scenarios of climate change (with predictions for 2050 and 2070), the spread of C. gestroi is well anticipated ${ }^{2,10}$. With these prediction models, we hypothesize, that if native populations of $C$. gestroi are present in India, they would have been reported often as the country possesses both geographic and climatic suitability for their distribution. After six decades of its first report in India $^{3}$, the first confirmative transportation pathway of $C$. gestroi straight from the neotropics to the Indian mainland, raises serious concerns on the quarantine measures taken at the place of origin for checking the spread of serious invasive pest species. Furthermore, from visual inspection, this pest species most probably has entered through the wooden structures/packaging material used for shipping a consignment from Harrisonburg, Virginia, USA, as the consignment was intact during transit and on receipt until the box was opened. During the course of transit, the termite images emerged and subsequent mortal remains (in the absence of any possible escape route) were observed and later recovered after opening the box (Figure 3). It is well proven that boat infestations ${ }^{21}$ have accelerated the spread of $C$. gestroi along the coasts of tropical Florida ${ }^{22}$ and numerous West Indian islands ${ }^{23}$.

The discovery of this unwelcome and serious invasive species in India can be considered as a fortunately failed reintroduction owing to anthropogenic dispersal. As the adults were recorded, there will be high chances of colonization in the area of invasion. Also, it raises serious concerns about the execution of standard protocols for quarantine measures to be followed during export at the place of packaging (Harrisonburg, Virginia, USA). Finally a word of caution to all the quarantine authorities, exporters and importers involved. In this era of biosecurity threat and biological invasion, we need to be careful and proactive and while handling international trade.

1. Evans, T. A., Forschler, B. T. and Grace, K. J., Biology of invasive termites: a worldwide review. Ann. Rev. Ent., 2013, 58, 455474 .

CURRENT SCIENCE, VOL. 120, NO. 11, 10 JUNE 2021 
2. Buczkowski, G. and Bertelsmeier, C., Invasive termites in a changing climate: a global perspective. Ecol. Evol., 2017, 7, 974985.

3. Roonwal, M. L. and Chhotani, O. B., Termite fauna of Assam region, eastern India. Proc. Natl. Inst. Sci., India, 1962, 28B(4), 281-406.

4. Araujo, R. L., Termites of the neotropical region. In Biology of Termites, Vol. If (eds Krishna, K. and Weesner, E. M.), Academic Press, NY, 1970, pp. 527-571.

5. Su, N. Y., Scheffrahn, R. H. and Weissling, T., A new introduction of a subterranean termite, Coptotermes havilandi Holmgren (Isoptera: Rhinotermitidae) in Miami, Florida. Fla Entomol., 1997, 80(3), 408-411.

6. Yeap, B. K., Othman, A. S. and Lee, C. Y., Genetic analysis of population structure of Coptotermes gestroi (Isoptera: Rhinotermitidae) in Native and Introduced populations. Environ Entomol. 2011, 40, 470-476.

7. Kirton, L. G. and Brown, V. K., The taxonomic status of pest species of Coptotermes in Southeast Asia: resolving the paradox in the pest status of the termites, Coptotermes gestroi, C. havilandi and C. travians (Isoptera: Rhinotermitidae). Sociobiology, 2003, 42(1), 43-63.

8. Su, N.-Y., A case of mistaken identity: all the evidence pointed to the Formosan subterranean termite, but closer inspection proved it wasn't so. Pest Control, 1994, 62(10), 7980.

9. Su, N.-Y. and Scheffrahn, R. H., Coptotermes vastator Light (Isoptera: Rhinotermitidae) in Guam. Proc. Hawaiian Entomological Soc., 1998, 33, 13-18.

10. Li, H. F., Fujisaki, I. and Su, N. Y., Predicting habitat suitability of Coptotermes gestroi (Isoptera: Rhinotermitidae) with species distribution models. J. Econ. Entomol., 2013, 106, 311-321.

11. Chouvenc, T. et al., Revisiting Coptotermes (Isoptera: Rhinotermitidae): a global taxonomic road map for species validity and distribution of an economically important subterranean termite genus. Syst. Entomol., 2016, 41, 299-306.

12. Maiti, P. K., A taxonomic monograph on the world species of termites of the family Rhinotermitidae (Isoptera: Insecta). Memoirs Zool. Surv. India, 2006, 20, 1-272.

13. Harit, A. K., Gajalakshmi, S. and Abbasi, S. A., Swarming of the termite Coptotermes gestroi in north-eastern Puducherry. Zool. Ecol., 2014, 24(1), 62-69.

14. Rathore, N. S. and Bhattacharyya, A. K., Termite (Insecta: Isoptera) Fauna of Gujarat and Rajasthan. Present State of Knowledge. Records of the Zoological Survey of India, Occasional Paper 223 , 2004, pp. 1-777.

15. Krishna, K., Grimaldi, D. A., Krishna, V. and Engel, M. S., Treatise on the Isoptera of the World: Vol. 3. Bull. Am. Museum Nat. Hist., 2013, 377, 623-973.

16. Hebert, P. D. N., Cywinska, A., Ball, S. L. and Dewaard, J. R., Biological identifications through DNA barcodes. Proc. Biol. Sci., 2003, 270, 313-322.

17. Sambrook, J. and Russell, D. W., Molecular Cloning: A Laboratory Manual, Cold Spring Harbor Laboratory Press, New York, 2001.

18. Kirton, L. G. and Azmi, M., Patterns in the relative incidence of subterranean termite species infesting buildings in peninsular Malaysia. Sociobiology, 2005, 46, 1-15.

19. Nagaraju, D. K. et al., First interception of two wood feeding potential invasive Coptotermes termite species in India. Int. J. Trop. Insect Sci., 2020; https://doi.org/10.1007/s42690-020-00287-5

20. Jones, R., Silence, P. and Webster, M., Preserving History: Subterranean Termite Prevention in Colonial Williamsburg. Colonial Williamsburg Foundation, Williamsburg, USA, 2015; http:/ museumpests.net/wpcontent/uploads/2015/03/Preserving-HistorySubterranean-Termite-Prevention-in-Colonial-Williamsburg1.pdf

21. Scheffrahn, R. H. and Crowe, W., Ship-borne termite (Isoptera) border interceptions in Australia and onboard infestations in Florida, 1986-2009. Fla Entomol., 2011, 94, 57-63.
22. Hochmair, H. H. and Scheffrahn, R. H., Spatial association of marine dockage with land-borne infestations of invasive termites (Isoptera: Rhinotermitidae: Coptotermes) in urban South Florida. J. Econ. Entomol., 2010, 103, 1338-1346.

23. Scheffrahn, R. H. et al., Proliferation of the invasive termite Coptotermes gestroi (Isoptera: Rhinotermitidae) on Grand Cayman and overall termite diversity on the Cayman Islands. Fl. Entomol., 2016, 99(3), 496-504; http://www.bioone.org/loi/flen

24. Li, Z.-Q., Liu, B.-R., Li, Q.-J., Xiao, W.-L. and Zhong, J.-H., Two new synonyms of Coptoterems gestroi (Wasmann) (Isoptera: Rhinoetermitidae) in China. Sociobiology, 2011, 58(2), 449-455.

ACKNOWLEDGEMENTS. We thank to the Director, ICAR-National Bureau of Agricultural Insect Resources, Bengaluru for providing the necessary facilities to carry out this work. C.M.K. thanks the Ministry of Environment, Forest and Climate Change, Government of India for funds under AICOPTAX (F. No. 22018-28/2019-CS (Tax).

Received 12 February 2021; revised accepted 11 May 2021

doi: $10.18520 / \mathrm{cs} / \mathrm{v} 120 / \mathrm{i} 11 / 1778-1781$

\section{Laevicaulis haroldi (Veronicellidae: Gastropoda), a potential future invader to India}

\author{
Biswa Bhusana Mahapatra ${ }^{1,2}$ and \\ N. A. Aravind ${ }^{1,3, *}$ \\ ${ }^{1}$ Ashoka Trust for Research in Ecology and the Environment (ATREE), \\ Royal Enclave, Srirampura, Jakkur, Bengaluru 560 064, India \\ ${ }^{2}$ Manipal Academy of Higher Education, Manipal 576 104, India \\ ${ }^{3}$ Yenepoya Research Centre, Yenepoya (Deemed to be University), \\ University Road, Derlakatte, Mangalore 575 018, India
}

Invasive alien species are considered one of the greatest threats to biodiversity, ecosystem services, economy and human health. Global climate change will only exacerbate the impact of several invasive species in the introduced range. Hence the control and management of invasive species is crucial. Spatial tools such as GIS/RS and ecological niche models can help understand the potential region where the species might invade and predict invasive spread under different climate change scenarios. This study explores if the newly introduced slug from South Africa, Laevicaulis haroldi (Purcell's hunter slug or caterpillar slug) will become invasive in India under current as well as future climate scenarios. Our result suggests that most parts of western and Peninsular India are vulnerable to the invasion, and suitable regions will only increase

*For correspondence. (e-mail: aravind@atree.org) 